Trivent Publishing

(C) The Authors, 2016

Available online at http://trivent-publishing.eu/

Series: Engineering and Industry

Volume: Watershed and River Basin Management

\title{
Climate Change: Towards an Adaptive Water Management in Slovenia
}

\author{
B. Đurović, ${ }^{1}$ A. Bizjak, ${ }^{1}$ M. Kobold ${ }^{2}$ \\ ${ }^{1}$ Institute for water of the Republic of Slovenia, Hajdrihova ul. 28c, SI-1000 Ljubljana \\ blazo.djurovic@izvrs.si; ales.bizjak@izvrs.si \\ ${ }^{2}$ Environmental Agency of the Republic of Slovenia, Vojkova c. 1b, SI-1000 Ljubljana, mira.kobold@gov.si
}

\begin{abstract}
The changes in climate parameters induce hydrometeorological circumstances, which are very likely to influence current water management regimes in a significant manner. Thus, particularly water balance and water related natural hazards should be thoroughly considered. The possible effects are challenging us to search for a new balance between water availability and demand as well as between natural hazards and socio-economically acceptable risks. The adaptation to extreme water quantity situations is becoming the key water management issue worldwide. This paper gives an overview on climate change related risks in Slovenia. A way towards an adaptive water management is taken by identifying the key issues of the future national adaptation strategy, which should be aimed at building adaptive capacity and reducing sectoral instability. A strategy should be introduced into the existing programmes for the implementation of the EU Directive 2000/60/EC (Water Framework Directive) through the next planning cycles, taking in consideration the climate change hazard indicators, impact vulnerability factors, risk levels and corresponding adaptation measures.
\end{abstract}

\section{Keywords}

Climate change; water management; climate change adaptation; national adaptation strategy

This is an Open Access article distributed in accordance with the Creative Commons Attribution Non Commercial (CC-BYNC-ND 4.0) license, which permits others to copy or share the article, provided original work is properly cited and that this is not done for commercial purposes. Users may not remix, transform, or build upon the material and may not distribute the modified material (http://creativecommons.org/licenses/by-nc/4.0/) 


\section{Introduction}

After recognizing that most of the global average warming over the past 50 years is very likely due to anthropogenic greenhouse gases increase (IPCC, 2007), a new challenge to the paradigm of sustainable development has been put up. Climate change impacts will strongly influence social, economic and environmental systems. The surface water and groundwater bodies and their catchment areas are an important environmental subsystem from which the other two systems depend. The changes can negatively affect the global, regional and local conditions of water resources and increase hydrometeorological natural hazards. The most important indicators of climate change are the enhanced frequency and magnitude of hazardous events and the changed spatial and temporal distribution of water quantities. Relying solely on climate change mitigation measures (improving energy efficiency and lowering emissions of greenhouse gases and aerosols) will not be enough since we are facing the change of climate also due to the pressure from the past. Thus, societies worldwide face the parallel challenge of having to adapt to climate change impacts (EU Commission, 2007).

Consistent complementary adaptation measures, applied to natural and human systems, could override the uncertainty of climate change evolution and, in some cases, deliver instant benefits (Figure 1). Proactive adaptation has a better risk-opportunity and cost-benefit ratio comparing to reactive adaptation, because anticipating future climate challenges ensures that the effects on newly designed social and economic systems are minimized. To prevent or limit the severe damage to the environment, society and economies, and to ensure sustainable development even under changing climate conditions, adaptation strategies for affected systems are required at European, national, regional and local levels (EEA, 2004).

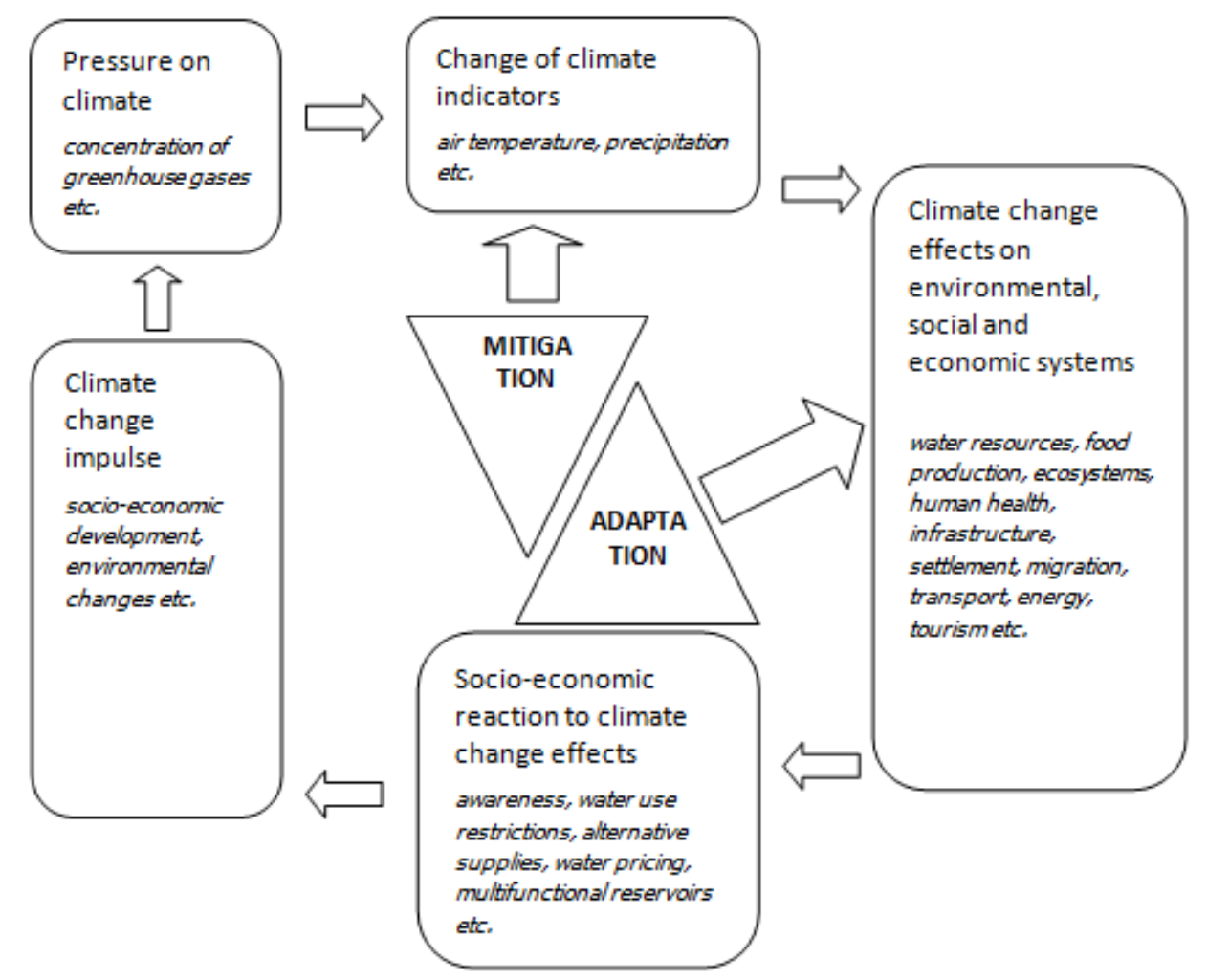

Fig. 1. Cycle of the anthropogenically induced climate change 
The global temperature shift is causing regional and local change of spatial and temporal variability of climate parameters. Climate change studies predict a significant decrease of average quantities of precipitation in Slovenia and consequently the decrease of stream water (EEA, 2004). According to the predictions of global climate models by the end of this century the temperature in Slovenia will increase, the least in spring (from $2.4{ }^{\circ} \mathrm{C}$ to $3.4{ }^{\circ} \mathrm{C}$ ) and the most in summer (approx. $4{ }^{\circ} \mathrm{C}$ ). The changes in temperatures will raise evapotranspiration rate and consequently cause the variations in amount and intensity of precipitation. The total amount of precipitation will be higher in winter (for 5 to $10 \%$ ) and lower in summer (up to $20 \%$ ). That indicates warmer and drier summers, less snow and more extreme weather. Due to anticipated climate change the potentially vulnerable areas in Slovenia are those with drinking water supply problems, drought and erosion-prone areas, sea and river flooding areas, torrential watercourses and deforestated areas (Bizjak, 1999). Thus, water management sector in Slovenia should adopt its national adaptation strategy, which would deal predominantly with floods, droughts and water scarcity. The strategy must follow up the demands on local, regional and national levels and should be implemented through the existing water policy frameworks, plans and programmes.

The comparison of the elements of the water balance in the 1971-2000 period with that in the 1961-1990 period already indicates an increase in evaporation and a reduction in the runoff. However, the comparison is not suitable for the establishment of potential tendencies in the variation of phenomena (EARS, 2008). A better comparison of some values of meteorological variables for periods 1961-1990 and 1991-2005 is shown in Table 1.

Table 1. Comparison of average yearly values of meteorological variables for periods 1961-1990 and 1991-2005 in Ljubljana (Kajfež-Bogataj, 2007).

\begin{tabular}{llll}
\hline & $1961-1990$ & $1991-2005$ & trend \\
\hline Air temperature $\left({ }^{\circ} \mathrm{C}\right)$ & 9.8 & 11.0 & ++ \\
Number of days with $\mathrm{T}_{\min } \leq 0^{\circ} \mathrm{C}$ & 89.6 & 78.8 & - \\
Number of days with $\mathrm{T}_{\max } \geq 25^{\circ} \mathrm{C}$ & 60.6 & 77.2 & + \\
Relative moisture at $14 \mathrm{~h}(\%)$ & 62.4 & 59.1 & - \\
Duration of insolation $(\mathrm{h})$ & 1712 & 1950 & ++ \\
Yearly precipitation $(\mathrm{mm})$ & 1393 & 1356 & - \\
Number of days with snow cover at $7 \mathrm{~h}$ & 64.9 & 49.0 & - \\
Number of days with precipitation $\geq 1.0 \mathrm{~mm}$ & 114.8 & 108.0 & - \\
\hline
\end{tabular}

In addition, higher average air temperatures, higher evapotranspiration rate, more variable quantity of precipitation, and shorter duration of snow cover can be expected. Slovenia is a water abundant country although in the last thirty years the decline of water quantities in rivers is notable, especially in the last decade when we have had droughts in late spring and summer and floods in fall (Kobold, 2007). The discharges at the majority of the water gauging stations analysed of period 1971-2000 have a decreasing trend in the mean daily discharges, even in the high water trends, though with a 
greater spatial variation in the statistical significance of the established trends (EARS, 2008). Runoff scenarios in case of positive or negative change of yearly precipitation can be found in Table 2.

Table 2. Future discharge changes in dependance of temperature and precipitation change (Rogelj, 1999).

\begin{tabular}{lllll}
\hline Air temperature change $\left({ }^{\circ} \mathrm{C}\right)$ & +1 & \multicolumn{3}{c}{+2.5} \\
\cline { 2 - 5 } Precipitation change $(\%)$ & +10 & -10 & +10 & -10 \\
\hline \multirow{2}{*}{ river basin } & \multicolumn{3}{c}{ runoff change } \\
\cline { 2 - 5 } & $(\%)$ & -26 & -2 & -37 \\
\hline Adriatic rivers & 10 & -69 & -34 & -114 \\
Mura & 10 & -33 & -7 & -50 \\
Drava & 10 & -24 & 0 & -34 \\
Sava & 10 & -17 & 4 & -23 \\
Soča & 10 & -24 & -1 & -35 \\
Kolpa & 10 & & & \\
\hline
\end{tabular}

In addition, climate scenarios predict the precipitation intensity increase by $20 \%$. Due to a relatively large climate, geological, fluvial and landscape differences in Slovenia, the highest runoff response is expected in alpine and pre-alpine region where the flood peaks could be higher up to $30 \%$ (Kobold, 2007). There is no linear relationship between the rise in precipitation and height of flood wave (Kobold and Brilly, 2006). More local flash floods combined with landslides and debris flow have already been registered in recent years (Kobold, 2006; Sušnik et al., 2007). Among them some extreme flood discharges were recorded which exceeded periodical maximum discharges and the 100year return period of floods.

Local and regional climate parameters are not reflected in the global models so the global level findings must be downscaled to regional climate scenarios which can be then used in water balance models to allow quantitative statements to be made about flow, groundwater recharge and evaporation (LAWA, 2007). National strategies depend on the reliable predictions of change in climate parameters but the findings from the global climate models are difficult to apply to Slovenia because of great climate diversity and small country surface area, which is comparable to the global climate model resolution. Bridging the gap between the local and global scales is possible through empirical downscaling based on mathematical models for relations between local and global size variable and measured values from the past, which is well described in Kajfež-Bogataj et al. (2003).

\section{Climate change impacts on the water sector in slovenia}

According to the recent hydrometeorological research even minor changes in spatial and temporal distribution of precipitation in Slovenia could cause heavy regional problems with floods, droughts and water scarcity. The relatively short and intensive rainfall can cause flash floods on the river basin and subbasin scales. Watercourses in Slovenia are predominantly of a torrential type with a strong 
erosion component and short response time (VGI, 1990). Flash floods are usually accompanied by many minor landslides causing mudflows, even debris flow. According to Pruski and Nearing (2002) the changes in precipitation amount and intensity have a strong effect on the soil erosion shift. In the past 40 years Slovenia experienced 9 drought events, and from that 6 in the last 15 years (KajfežBogataj, 2005). Most endangered are the coastal and north-eastern areas where the total yearly amount of precipitation is the lowest and the deficit of precipition is usually the highest. Decline in the amount of available water by $0,15 \mathrm{~km}^{3}$ per year compared to $32,1 \mathrm{~km}^{3}$ of yearly average amount (1961-2000) indicates that the decline is not only due to increased water use but also due to changes in climate conditions (RS MOP, 2006). Areas with highest losses in water supply are the most vulnerable in case of climate change (Bizjak, 1999). Several possible climate change consequences to the water environment are listed in the interim report on significant water management issues (IzVRS, 2007) in the context of the Water Framework Directive.

The changes in climate indicators could impact the water sector in Slovenia in two significant ways (Table 3): (i) enhanced probability of occurrence and magnitude of extreme hydrological events, i.e. floods, flash floods, hydrological droughts, landslides, erosion, sea water rise, and meteorological events, i.e. short and intensive rainfall, meteorological drought, heatwaves, storms, winds, frost, fires, (ii) water scarcity meaning that the water demand is unable to cope with water availability, e.g. decrease in average annual discharges of rivers and groundwater storage.

Table 3. Relations between the indicators and effects of climate change and potential adaptation measures

\begin{tabular}{|c|c|c|}
\hline $\begin{array}{l}\text { Climate change } \\
\text { indicator }\end{array}$ & Climate change effect & Possible adaptive reaction of water sector \\
\hline ALTERATIONS: & CONSEQUENCES: & $\begin{array}{lll}\text { WATER } & \text { RELATED } & \text { NATURAL } \\
\text { HAZARDS: } & & \end{array}$ \\
\hline
\end{tabular}

Air temperature extremes (frequency, intensity, duration)

Precipitation extremes (frequency, intensity, duration)

River discharge extremes, sea level extremes
Frost, heatwave, fire, storm

(wind, thunder, hail, shower)

Drought (meteorological, agricultural), soil erosion, sewage system overload, landslides

Drought (hydrological), flash flood, flood, streambed and lateral erosion, reduced electricity production, pollution risk
Early warning systems, temporary relocation, improved disaster response capabilities

Watershed management, erosion protection works, redimensioning of sewage systems, crop adaptation, water transfer

Re-evaluation of water infrastructure protection capacity, additional detention ponds, spatial planning legislation and zonation, preservation of the existing, restoration of the former, and reservation of future retention areas, awareness and warning systems, insurance 
ALTERATIONS:

Average air temperature

Average annual precipitation and snow cover (amount, extent, duration)

Average annual river discharge, sea level rise
CONSEQUENCES:

Increase in surface water and sea temperature, increased evapotranspiration, increased water demand

Surface water and groundwater quantity, water availability for irrigation, soil moisture deficiency, plant water stress, reduced biomass and yield

Change of discharge regimes, river and sea sediment transport, coastline migration, groundwater level rise, salinization, hydropower

\section{WATER RESOURCES:}

Prioritization of water use, temperature tolerant crops

Crop adaptation strategy, land use, mulching, water supply reservoirs, groundwater recharge, reduction of distribution system leaking, water pricing, use of surface water, recycling water

Land use change, adaptive spatial planning, reduction of water use demand, desalinisation, additional water storage

\section{Towards an adaptation strategy in Slovenia}

After a profound expert discussion on climate change impacts on the water cycle, resources and quality (EU Commission, 2006) and adaptive water policy dimension (BMU, 2007) the Green Paper (EU Commission, 2007) introduced the options for European action to ensure the coherency in exposing the adaptation challenges and create an appropriate policy response through the four main pillars: early action, external integration, reducing uncertainty and coordinated and comprehensive adaptation strategies. Early action should be comprehended through the integration of adaptation when implementing and modifying the existing and forthcoming legislation and policies as well as through integration into the existing Community funding programmes and development of new policy responses. The cross-sectoral cooperation should integrate policy implementation and narrow the knowledge gap by defining additional research needs. Information, participation and consultation processes are the key elements of a successful response to the climate change impacts. Development of the adaptation strategy has to deal also with the financial instruments for lowering the risks and promoting opportunities.

According to the Australian national climate change adaptation framework (2007), two priority areas for potential action within the next five to seven years are: (i) building understanding and adaptive capacity and (ii) reducing vulnerability in key sectors and regions. The framework should make the decision-makers understand and incorporate climate change into policy and operational decisions at all scales and across all vulnerable sectors. The future Slovenian national climate change adaptation strategy should understand all levels of climate change demands, i.e. global, supranational, national, regional and local scale demands. The adaptation strategy must be based on building of competency, improving adaptive capacity and reducing the risks. The strategy should consist of identification of relations between climate change effects, water related environmental and socioeconomic systems and feasible integrated subsectoral reactions, building of competent decision- 
making knowledge base, risk-opportunity analysis considering the adaptive capacity and intersectoral and interregional system dependence, adaptation measures, public awareness and policy monitoring (Figure 2).

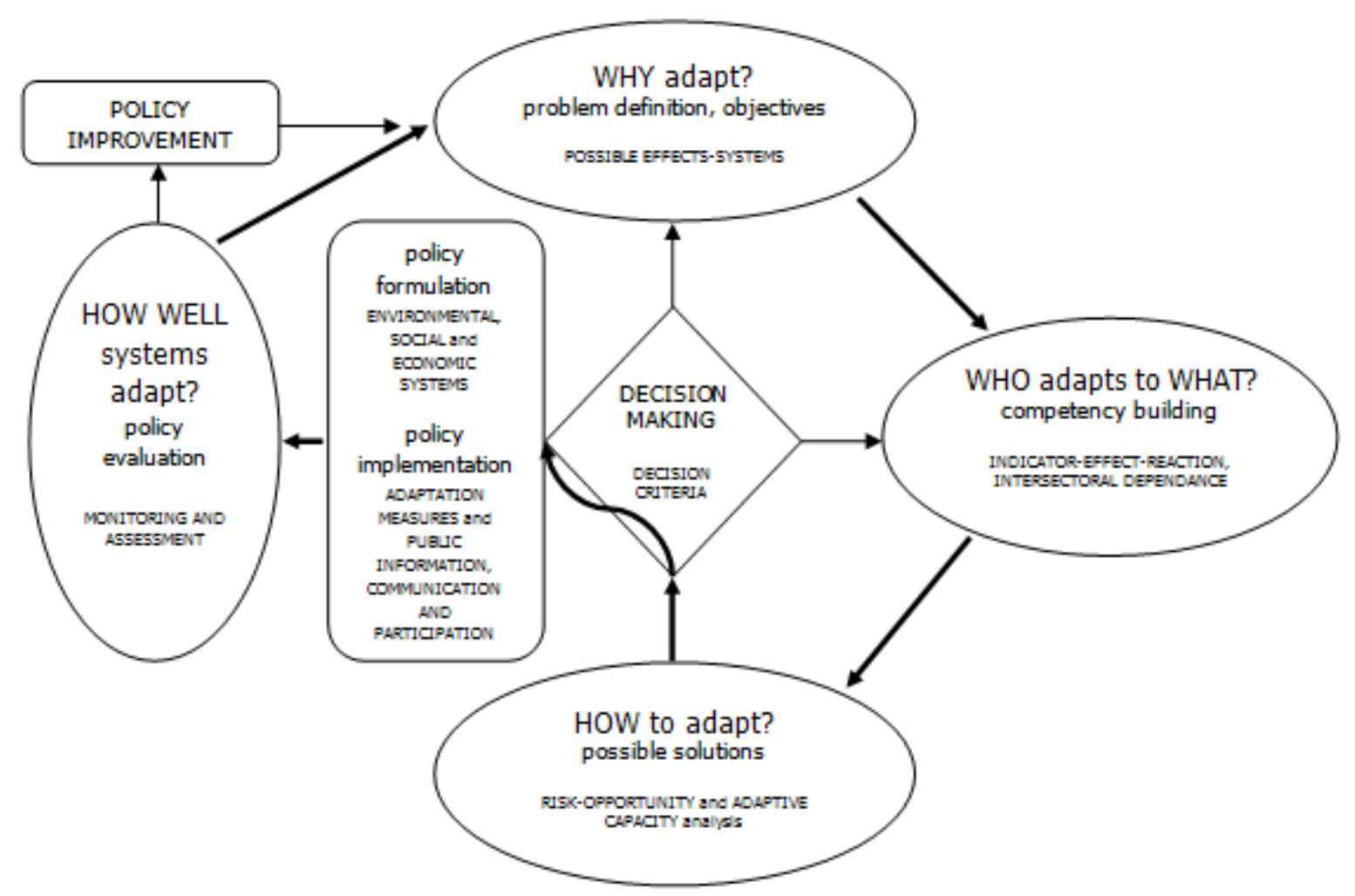

Fig. 2. Proposal for a national climate change adaptation strategy concept.

Competency can be built by integrating the research, e.g. projections of climate change indicators, effects on environmental, social and economic systems, improving the decision-making information e.g. risks and opportunities, costs and benefits, assessment methods on national, regional and local scales, managing the information by a clear communication strategy for broad stakeholder participation and by "comprehensive understanding achieved by open, shared information sources that fill gaps and facilitate integration (NeWater, 2007)". The improved adaptive capacity should be achieved through the integration of sectors and regions by identifying and analysing problems and integrating policy implementation. Implications for other countries are also an important adaptive capacity issue.

The reduction of risks should deal with water resources (e.g. demand-availability, water infrastructure), human health (e.g. public health system), spatial planning (e.g. codes, standards and guides; critical infrastructure, insurance industry partnership, tools for regional and local adaptation), and preventive management of risks due to water related natural hazards (e.g. hazard - vulnerability risk, prevention, warning and response systems, project values).

Integrated and adaptive water management regime uses financial resources that should be diversified using a broad set of private and public financial instruments (NeWater, 2007). Embedding adaptation strategies into the existing national water policy frameworks and programmes should be made in a way that converges with significant water management issues and programme of costeffective measures. This process would ensure the "climate proof" water management investments. 
The climate change related risks also evoke the demand for new management regimes and strategies, which will be able to integrate and adapt since they are unable to reliably predict and control. The transition from the current management regimes to more adaptive regimes implies a paradigm shift in water management from a prediction and control to a management as a learning approach (Pahl-Wostl, 2007). The River Basin Management Plans under EU Directive 2000/60/EC (Water Framework Directive), Flood Risk Management Plans under Directive 2007/60/EC (Flood Directive), and Drought Management Plans (EU Commission, 2007b) should consider adaptation challenges in their programmes of measures.

\section{Conclusions}

With a growing sense of climate variability it is important to reassess floods along with droughts and water scarcity as phenomena related through the change of climate conditions. The important climate change effects in Slovenia will be the enhanced water related natural hazards and water demand as well as reduced water availability. The preventive risk management and disaster mitigation strategies will have to adapt to the conditions of extreme meteorological, hydrological and geological risks. The collision between hazard and damage potential is becoming more probable and more severe, and higher vulnerability and lower adaptive capacity are closely linked to the economic value and total risk.

Watercourses in Slovenia are predominantly of torrential character so the intensive local or regional precipitation events can cause major flash floods accompanied by strong streambed and lateral erosion, thus seriously affecting parts of river basins. On the other hand altered air temperature is affecting evapotranspiration and precipitation deficit including snowfall is causing river discharge values decline, and in case of long duration of low flow the hydrological drought appears. Thus, drought originates from a deficiency of precipitation over an extended period of time, usually a season or more. This deficiency results in a water shortage for different activities, economic, or environmental sector. Other climatic factors such as high temperature, strong wind, and low relative humidity are often associated with it and can significantly aggravate its severity. The economic damage is in the case of drought highly related with crop growth stages. Predicted climate change will also have a significant implication for the hydropower sector and water quality. One of the adaptive technical solutions could be appropriately located multifunctional retention ponds satisfying different needs (e.g. floods, droughts, water scarcity, and energy).

Slovenia should develop a national climate change adaptation strategy to be able to cope with the danger of water scarcity, drought and hydrometeorological natural hazards. The concept of integrated and adaptive water management, implemented through the cyclical process of river basin management plans including the flood risk management plans and drought management plans, can realize and resolve regionally characteristic and intersectorally dependant problems of quantity extremes and averages (e.g. floods, droughts and water scarcity) as well as their relations to water quality. The paper gives a contribution to a future national adaptation strategy building, which should primarily lower the water quantity demand, enhance the adaptive capacity to water related natural hazards, and protect the ecosystem balance. 


\section{References}

1. Bergant, K., Kajfež-Bogataj, L. (2004). Some methods for preparation of the regional climate change scenarios (in Slovene). Acta Agriculturae Slovenica, 2004, vol. 83, No. 2, 273-287.

2. Bizjak, A. (1999). Climate Changes, Flood Prevention and Water Supply in Slovenia (in Slovene). Urbani izziv, vol. 10, No. 1/99, 25-29.

3. BMU (2007). Time to adapt, Climate change and the European Water Dimension, VulnerabilityImpacts-Adaptation. Bundesministerium für Umwelt, Naturschutz und Reaktorsicherheit, Symposium report, February 12-14 2007, Berlin.

4. Council of Australian Governments (2007). National Climate Change Adaptation Framework. Available at: www.coag.gov.au/meetings/130407/docs/national_climate_change_adaption_framework.pdf

5. EARS (2008). Water balance of Slovenia 1971-2000. Environmental Agency of the Republic of Slovenia. Available at: www.arso.gov.si

6. EEA (2004). Impacts of Europe changing climate. An indicator-based assessment. European Environment Agency, Copenhague (Denmark), Report No. 2/2004, Office for official publications of the European communities, Luxembourg, 107 p. Available at: www.eea.eu.int

7. EU Commission (2006). Climate change impacts on the water cycle, resources and quality. Workshop report, September 25-26 2006, Bruxelles.

8. EU Commission (2007). Green Paper, Adapting to climate change in Europe - options for EU action. COM (2007) 354 final.

9. EU Commission (2007b). Addressing the challenge of water scarcity and droughts in the European Union. Communication COM(2007) 414 final.

10. IPCC (2007). Climate change 2007: Synthesis report. Intergovernmental Panel on Climate Change, IPCC Plenary XXVII. Valencia, Spain, 12-17 November 2007. 72 p. Available at: www.ipcc.ch

11. IzVRS (2007). Interim report on Significant Water Management Issues - surface water. Institute for water of the Republic of Slovenia, Ljubljana.

12. Kajfež-Bogataj, L., Bergant, K., Črepinšek, Z., Cegnar, T., Sušnik, A. (2003). Climate change scenarios as a foundation for risk assessment due to future weather related natural hazards (in Slovene). Available at: www.sos112.si/slo/tdocs/crp_scenariji.pdf

13. Kajfež-Bogataj, L., Bergant, K. (2005). Climate change in Slovenia and drought (in Slovene). Ujma, No. 19, 37-41.

14. Kajfež-Bogataj, L. (2007). Climate change effects on water resources and water supply in Slovenia (in Slovene). Parliamentary group GLOBE Slovenija and the Council for Environmental Protection of the Republic of Slovenia, $2^{\text {nd }}$ joint session, 20. 3. 2007. Available at: 212.18.47.244/web/portal.nsf/

15. Kobold, M. (2006). High water and flood in August 20-23 2005 (in Slovene). Ujma, No. 20. Republic of Slovenia, Administration for Civil Protection and Disaster Relief, Ljubljana. 48-55.

16. Kobold, M., Brilly, M. (2006). The use of HBV model for flash flood forecasting. Nat. Hazards Earth Syst. Sci., No. 6, 407-417. Available at: www.nat-hazards-earth-syst-sci.net/6/407/2006/.

17. Kobold, M. (2007). Climate change effects on Slovenian river discharges (in Slovene). Symposium proceedings, $18^{\text {th }}$ Mišič water day, Maribor.

18. LAWA (2007). Climate Change - Impacts on Water Resources Management. Strategy paper, first draft 07.09.2007. Bund/Länder-Arbeitsgemeinschaft Wasser, $133^{\text {th }}$ Plenary Meeting, Trier. 
19. NeWater (2007). Adaptive Water Management: How to cope with uncertainty? New Approaches to Adaptive Water Management under Uncertainty, Integrated Project in the 6th EU Framework Programme, Policy Brief No. 4. Available at: www.newater.info

20. Pahl-Wostl, C. (2007). Transitions towards adaptive management of water facing climate and global change. Water Resources Management, No. 21, 49-62

21. Pruski, F. F., Nearing, M. A. (2002). Runoff and soil loss responses to changes in precipitation: $a$ computer simulation study. Journal of Soil and Water Conservation, No. 57(1), 7-16.

22. Rogelj, D. (1999). Assessment of climate change effects on hydrological conditions of Slovenian watercourses (in Slovene). Environmental Agency of the Republic of Slovenia, Ljubljana.

23. RS MOP (2006). Fourth national report to the conference of parties to the United Nations Framework Convention on Climate Change. Republic of Slovenia, Ministry of environment and spatial planning.

24. Sušnik, M., Robič, M., Pogačnik, N., Ulaga, F., Kobold, M., Lalić, B., Vodenik, B., Štajdohar, M. (2007). High water and floods in September 2007 (in Slovene). Symposium proceedings, $18^{\text {th }}$ Mišič water day, Maribor.

25. VGI (1990). Water management base of Slovenia (in Slovene). Water Management Institute, Ljubljana. 